\title{
A QUANTITATIVE PRECIPITATION TEST FOR SYPHILIS
}

BY

\author{
I. N. ORPWOOD PRICE \\ Venerzal Diseases Reference Laboratory, Medical Research Council
}

(RECEIVED FOR PUBLICATION, MARCH 26, 1947)

In February, 1946, under the title of "A Preliminary Report on a Modification of the Kahn Test" (Price, 1946a), the author described a modification of the Kahn test, the advantages of which were stated to be: (1) that the results are more easily read than those of the Kahn test; (2) the results given by antigens prepared at different times and having different titres are identical; (3) the results obtained by this test appear to be somewhat more specific than those given by either the Kahn or Wassermann reactions. After more than 3,000 tests there seems to be no reason to modify these opinions.

One major disadvantage remained, that is, the difficulty in the preparation of the alcoholic extract of dried heart muscle according to Kahn's technique. If, moreover, one considers the production of the dried heart powder itself, the manufacture of Kahn antigen is outside the scope of most pathological laboratories. It is, therefore, desirable from all points of view to attempt to prepare an antigen which can be made in any laboratory, is specific in action, reasonably sensitive, and easy to handle.

\section{Experimental}

The starting point was the standard cholesterolized alcoholic extract of heart muscle used in the HarrisonWyler (1929) technique of the Wassermann reaction. The lipoids were precipitated as described in the previous paper, and an attempt was made to work out a precipitation titre (Price, 1946b). Unfortunately, whilst positive sera gave fairly strong reactions all the negative serum and saline tubes contained a faint precipitate which was thought to be due to excess of cholesterol.

Accordingly, in the next experiment, Wassermann reaction alcoholic heart extracts containing varying quantities of cholesterol from 0.05 to $\mathbf{0 . 3}$ per cent were used. The precipitation titres obtained with the various antigens were:

W.R. alcoholic extract $+0.05 \%$ cholesterol 1 to 0.8 saline

\begin{tabular}{|c|c|c|c|c|c|}
\hline ," & ," & , & $0.1 \%$ & ," & 1 to 1.0 saline \\
\hline ," & ,", & ,, & $0.2 \%$ & ," & 1 to 1.4 saline \\
\hline " & $\because$ & , & $0.3 \% *$ & ", & $\begin{array}{l}\text { no titre ob- } \\
\text { tainable; fine } \\
\text { precipitate in } \\
\text { all tubes. }\end{array}$ \\
\hline
\end{tabular}

*It should be pointed out that cholesterol at 0.3 per cent strength in the alcoholic extract required heat at $37^{\circ} \mathrm{C}$. to effect solution and on regaining room temperature the cholesterol precipitated out from the solution.
When these antigens were tested by the method of optimal proportions (Price, 1946b), the best results were obtained when the ratio of serum to antigen was 5 to 1 and the precipitate of lipoids from $1 \mathrm{ml}$. of the heart extract (cholesterolized) obtained by using the precipitation titre was suspended in $0.6 \mathrm{ml}$. of saline. On the other hand, when used in a test, the less the alcoholic extract was cholesterolized the larger became the precipitates obtained with positive sera. Thus the best reaction was obtained with the alcoholic extract of heart muscle containing 0.05 per cent cholesterol.

Plain uncholesterolized alcoholic extract of ox heart was then used as an antigen in the manner already described for the cholesterolized extracts. The results of these experiments are summarized in Table $I$.

TABLE I

\begin{tabular}{|c|c|c|}
\hline $\begin{array}{l}\text { Alcoholic extract of ox } \\
\text { heart } 9 \mathrm{ml} \text {. to the gramme }\end{array}$ & $\begin{array}{l}\text { Precipita- } \\
\text { tion titre }\end{array}$ & $\begin{array}{l}\text { Serum titre } \\
\text { of reacting } \\
\text { serum }\end{array}$ \\
\hline . $\quad \cdots$ & $\begin{array}{l}0.8 \mathrm{ml} \text {. saline } \\
\text { to } 1 \mathrm{ml} \text {. } \\
\text { heart extract }\end{array}$ & 80 units \\
\hline Plain $+0.05 \%$ cholesterol & $0.8 \mathrm{ml}$. saline & 80 units \\
\hline Plain $+0.1 \%$ cholesterol & $1.0 \mathrm{ml}$. saline & 40 units \\
\hline Plain $+0.2 \%$ cholesterol & $1.4 \mathrm{ml}$. saline & 20 units \\
\hline
\end{tabular}

It is evident that cholesterol as a sensitizer of this type of antigen was unimportant and could be omitted. The Wassermann reaction alcoholic extract of heart muscle used in the above experiments was obtained by extracting fresh wet ox heart muscle, cleaned from fat, with $9 \mathrm{ml}$. of absolute alcohol per gramme of muscle for 24 hours at $37^{\circ} \mathrm{C}$. After filtration the alcoholic extract was placed in the ice chest $\left(4^{\circ} \mathrm{C}\right.$.) for twenty-four hours and then refiltered.

Variations in the method of extraction were now investigated. Wet ox heart muscle was extracted for twenty-four hours, three days, and five days at $37^{\circ} \mathrm{C}$. and at room temperature for three and five days respectively. All these extracts gave identical precipitation titres, and if cholesterol were added in the various amounts mentioned above ( 0.05 per cent, 0.1 per cent, 0.2 per cent) the precipitation titres varied accordingly. Furthermore, if serum quantitative tests on positive sera 
were carried out using the same serum for each antigen, the unit values obtained varied in a similar manner to those obtained with the original extracts. In short, the method of extraction did not affect the precipitation reaction.

During these experiments it was noticed that when heat was employed in the extraction a deposit of crystals separated out from the alcoholic extract after about six weeks. These crystals could not be removed by filtration or centrifugalization, and they interfered with the reading of the tests as it was found that all tubes contained a fine deposit when examined with a $\times 6$ lens. Up to the time that crystals started to appear there was no interference with the test and they were regarded as a non-specific by-product of the heat-induced alcoholic extraction. As a result of these experiments the use of heat in the alcoholic extraction of the heart muscle was abandoned and extraction at room temperature was adopted as the routine method.

Hitherto all extracts had been prepared by extracting one gramme of the ox heart muscle with $9 . \mathrm{ml}$. of absolute alcohol. The next step was to ascertain what effect, if any, varying amounts of absolute alcohol per gramme of wet ox heart muscle would have on the quality of the antigen. The amounts used were $2.5 \mathrm{ml} ., 5 \mathrm{ml}$., and $15 \mathrm{ml}$. per gramme respectively. The results are shown in Table II.
The titrations given in the table below were repeated several times and the results obtained were always identical for the precipitation titres. At the same time unit values of sera of different strengths always bore the same proportion.

From these experiments it was concluded that

1. An alcoholic extract of ox heart obtained by using $2.5 \mathrm{ml}$. of absolute alcohol per gramme of muscle is useless as an antigen in this test.

2. The best results are obtained when an extract obtained by using $5 \mathrm{ml}$. of absolute alcohol per gramme of ox heart muscle is used.

3. The addition of cholesterol to the alcoholic extract of heart muscle in amounts of 0.05 per cent had no sensitizing action. Above this amount it inhibits the sensitivity of the extract as an antigen.

4. Whatever amount of absolute alcohol per gramme of ox heart is used to prepare an antigen, the best results are always obtained by using the plain extract without the addition of cholesterol.

It now remained to be shown which extract is the most sensitive antigen. Since plain alcoholic extracts

TABLE II

\begin{tabular}{|c|c|c|c|c|}
\hline $\begin{array}{l}\text { Each gramme of wet ox } \\
\text { muscle extracted by }\end{array}$ & heart & Antigen & $\begin{array}{l}\text { Precipitation titre in } \\
\text { terms of normal saline } \\
\text { to each ml. of heart } \\
\text { extract }\end{array}$ & $\begin{array}{l}\text { Value of } \\
\text { given serum } \\
\text { (in units) }\end{array}$ \\
\hline \multirow[t]{4}{*}{$2.5 \mathrm{ml}$. of absolute alcohol } & \multirow[t]{4}{*}{$\cdots$} & $\begin{array}{lll}\cdots & \cdots & \cdots\end{array}$ & $\begin{array}{l}\text { None obtainable: pre- } \\
\text { cipitate in all tubes }\end{array}$ & - \\
\hline & & Plain extract $+0.05 \%$ cholesterol & ", & 一 \\
\hline & & Plain extract $+0.1 \%$ cholesterol &, & - \\
\hline & & Plain extract $+0.2 \%$ cholesterol & , & - \\
\hline \multirow[t]{4}{*}{$5 \mathrm{ml}$. of absolute alcohol .. } & \multirow[t]{4}{*}{$\cdots$} & Plain extract $\ldots \quad \ldots$ & $0.6 \mathrm{ml}$ & 320 \\
\hline & & Plain extract +0.05 cholesterol & $0.6 \mathrm{ml}$ & 320 \\
\hline & & Plain extract $+0.1 \%$ cholesterol & $0.8 \mathrm{ml}$ & 80 \\
\hline & & Plain extract $+0.2 \%$ cholesterol & $1.0 \mathrm{ml}$ & 40 \\
\hline \multirow[t]{4}{*}{$15 \mathrm{ml}$. of absolute alcohol } & \multirow[t]{4}{*}{$\cdots$} & $\begin{array}{llll}\text { Plain extract } \ldots & \ldots & \ldots & \ldots\end{array}$ & $0.8 \mathrm{ml}$ & $20 *$ \\
\hline & & Plain extract $+0.05 \%$ cholesterol & $1.0 \mathrm{ml}$ & 20 \\
\hline & & Plain extract $+0.1 \%$ cholesterol & $1.2 \mathrm{ml}$ & 20 \\
\hline & & Plain extract $+0.2 \%$ cholesterol & $1.6 \mathrm{ml}$ & 20 \\
\hline
\end{tabular}

Whilst this titre could not be read at higher than 20 units, the precipitate was somewhat heavier than those given by the other antigens in the same class. 
of ox heart muscle had always proved the most sensitive of their group (with or without cholesterol added), the three plain extracts obtained by using $5 \mathrm{ml} ., 9 \mathrm{ml}$., and $15 \mathrm{ml}$. of absolute alcohol respectively per gramme of heart muscle were used as antigens in parallel with different sera of varying strengths. Many hundreds of sera were tested, but Table III gives a sample of ten sera tested at the same time.

The ten sera shown in the table were unselected except in so far as they came from one batch of sera tested by the Wassermann reaction. Of the antigens employed, it will be seen that that obtained by extracting $1 \mathrm{~g}$. of ox heart muscle with $5 \mathrm{ml}$. of absolute alcohol is the most sensitive, whilst between the other two there is little to choose. These results were repeated many times with similar results.

To conclude the experimental work the sensitivity of the antigen as described in the first paper was compared (Price, 1946c) with the sensitivity of the antigen prepared in the above manner. More than 1,000 sera were tested in parallel, and it was found that sera yielding 0 units with the one antigen always gave a similar result with the other. On the other hand, when sera yielding positive results were encountered, considerably higher values were given by the latter antigen than by the former. This may perhaps be best shown in the form of a graph (Fig. 1).

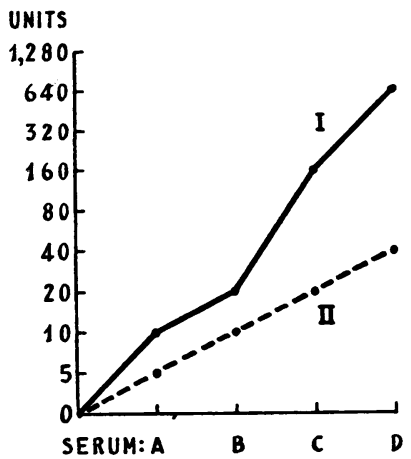

FIg. 1.-(I) Plain alcoholic heart extract antigen used. (II) Antigen prepared from Kahn extract.

\section{The Test Proper}

The above experimental work is a continuation of that contained in the first paper (Price, 1946a), and the test about to be described, henceforth referred to as the P.P.R.* for syphilis, is based on the technique as set out therein.

Apparatus required.-The necessary apparatus is as follows: Wassermann tubes $5 \mathrm{~cm}$. $\times 1.25 \mathrm{~cm}$.; Wassermann racks to hold tubes; pipette $\nmid$ to hold 5 volumes $(0.11 \mathrm{ml}$.); droppers $\dagger$ to hold 5 volumes $(0.11 \mathrm{ml}$.), for saline used in conjunction with Donald's dropping apparatus; 1 volume $(0.022 \mathrm{ml}$.); shaking apparatus, 280 oscillations per minute.

\footnotetext{
*Price's Precipitation Reaction.

tThe above volume $(0.022 \mathrm{ml}$.) is purely arbitrary and was adopted since the necessary pipette and droppers were already employed in Harrison. Wyler technique of the Wassermann reaction (M.R.C. report 1929) used in this laboratory. In addition it ensured a reasonable economy of serum and antigen.
}

TABLE III

\begin{tabular}{c|c|c|c|c|c}
\hline & $\begin{array}{c}\text { Antigen prepared by } \\
\text { extracting } 1 \text { g. of ox } \\
\text { heart with 5 ml. of } \\
\text { absolute alcohol }\end{array}$ & $\begin{array}{c}\text { Antigen prepared by } \\
\text { extracting } 1 \text { g. of ox } \\
\text { heart with 9 ml. of } \\
\text { absolute alcohol }\end{array}$ & $\begin{array}{c}\text { Antigen prepared by } \\
\text { extracting } \mathbf{1} \text { g. of ox } \\
\text { heart muscle with 15 } \\
\text { ml. absolute alcohol } \\
\text { No. }\end{array}$ & $\begin{array}{c}\text { W.R. } \\
\text { result }\end{array}$ & $\begin{array}{c}\text { Kahn test } \\
\text { result }\end{array}$ \\
\hline 1 & 40 units & 10 units & 10 units & ++ & Positive \\
\hline 2 & 80 units & 10 units & 10 units & ++ & Positive \\
\hline 3 & 320 units & 320 units & 320 units & ++ & Positive \\
\hline 4 & 40 units & 5 units & 5 units & ++ & Positive \\
\hline 5 & 0 units & 0 units & 0 units & Neg. & Negative \\
\hline 6 & 10 units & 5 units & 5 units & ++ & Positive \\
\hline 7 & 320 units & 160 units & 80 units & ++ & Positive \\
\hline 8 & 320 units & 40 units & 40 units & ++ & Positive \\
\hline 9 & 160 units & 40 units & 40 units & ++ & Positive \\
\hline 10 & 40 units & 5 units & 5 units & ++ & Positive \\
\hline
\end{tabular}


Preparation of the alcoholic heart extract.-An ox heart obtained from a freshly killed beast is obtained, stripped of fat, cut into small pieces, and weighed. The muscle is ground in a mortar for one minute with a few $\mathrm{ml}$. of the alcohol and glass powder. The mixture is then transferred to a suitable glass-stoppered bottle and the mortar washed out with a further few $\mathrm{ml}$. of the alcohol, the washings being then poured into the bottle. Sufficient alcohol is now added so that the bottle contains $5 \mathrm{ml}$. of alcohol for every gramme of heart muscle. The bottle is well shaken for a few seconds and placed in a dark cupboard or box for three days at room temperature, being shaken two or three times each day. At the end of this time the contents of the bottle are filtered into another glass-stoppered bottle, which is then placed in the ice chest $\left(4^{\circ} \mathrm{C}\right.$.) for 24 hours. Finally, whilst still cold; it is refiltered into a bottle of brown-coloured glass (to exclude light). The very pale-lemon-coloured filtrate is then ready for use.

Precipitation titre.-Before the antigen can be prepared for use in the test proper, the precipitation titre must be determined. This is done as follows. Four mixtures of $1 \mathrm{ml}$. of the alcoholic heart extract are made with respectively $0.4 \mathrm{ml} ., 0.6 \mathrm{ml}$., $0.8 \mathrm{ml}$., and $1 \mathrm{ml}$. of normal saline. The mixtures should be made by gently pouring the alcoholic extract down the inside of the small tube containing the saline and then pouring back into the tube which originally contained the extract. Gentle but thorough mixing is obtained by pouring and repouring seven times in all. The mixtures are allowed to stand for $\mathbf{3 0}$ minutes. The precipitate which forms in each tube is packed tightly into the bottom of the tube by centrifugalization (2,000 r.p.m.) for ten minutes, at the end of which time the supernatant fluid can be removed without fear of loss of any of the precipitate. The tubes are allowed to drain for five minutes by standing in the inverted position. Normal saline $(0.6 \mathrm{ml}$.) is added to each precipitate, and thorough mixture obtained by means of a Wright's capillary pipette. Thus four antigens are obtained, and these are titrated by adding one volume of each antigen to five volumes of known moderately positive serum, one volume to five volumes of normal serum, and one volume to five volumes of saline. After five minutes on a shaking machine, $1 \mathrm{ml}$. of saline is added to each tube. The rack containing the tubes is gently agitated and the results read by means of a $\times 6$ lens and a slit lamp. The precipitation titre is indicated by the tubes showing no precipitate and containing the antigen obtained by adding the least amount of saline to $1 \mathrm{ml}$. of the alcoholic heart extract. These tubes containing no precipitate are of course always in the normal serum and saline rows. The tubes containing moderately positive serum are not essential for the titration but are included for the sake of completeness.

This titration may be summarized as in Table IV. From the Table it is clear that the least amount of saline to be added to $1 \mathrm{ml}$. of the alcoholic extract (5 ml. to the gramme) of ox heart muscle in order to obtain a suitable antigen is $0.6 \mathrm{ml}$, , and this constitutes the precipitation titre. It is a matter of experience that, although very many of these extracts have been titrated, the precipitation titre has always been $0.6 \mathrm{ml}$. of normal saline to $1 \mathrm{ml}$. of the alcoholic extract of ox heart muscle. Furthermore, once this titre is determined for any given extract it remains constant. The amount of normal saline $(0.6 \mathrm{ml}$.) added to the precipitate to form the antigen has already been determined by the method of optimal proportions (Price, 1946b).

Preparation of antigen for use in the test pmoper.-Having ascertained the precipitation titre as $0.6 \mathrm{ml}$. of normal saline to $1 \mathrm{ml}$. of heart extract, a simple proportion sum will give the amounts of each reagent to mix to produce the amount of antigen necessary for a given number of tests. The practice in this laboratory is to make up enough for at least a week's work. To make $12 \mathrm{ml}$. of the antigen (enough for 300 to 400 serum tests) add $20 \mathrm{ml}$. of the alcoholic heart extract to $12 \mathrm{ml}$. of normal saline. This operation is performed by measuring $20 \mathrm{ml}$. of the alcoholic extract in one $50 \mathrm{ml}$. centrifuge tube and $12 \mathrm{ml}$. of normal saline into a similar tube. The alcoholic extract is first poured on to the saline, and then the mixture is poured back and forth six times, subsequently being allowed to stand for 30 minutes. (It is of the utmost importance that the alcoholic extract be poured on to the saline in the first instance, otherwise a very fine non-specific precipitate is apt to appear in all tubes of the test. This may confuse the readings,

TABLE IV

\begin{tabular}{|c|c|c|c|c|c|}
\hline \multirow[b]{2}{*}{$\begin{array}{l}\text { Alcoholic extract } \\
\text { of ox heart } 5 \mathrm{ml} \text {. } \\
\text { to } 1 \mathrm{~g} .\end{array}$} & \multirow{2}{*}{$\begin{array}{l}\text { Normal saline } \\
\text { added to obtain } \\
\text { precipitate }\end{array}$} & \multirow{2}{*}{$\begin{array}{l}\text { Saline added to } \\
\text { precipitate to } \\
\text { form antigen }\end{array}$} & \multicolumn{3}{|c|}{ Reaction precipitate } \\
\hline & & & $\begin{array}{l}\text { Syphilitic } \\
\text { serum }\end{array}$ & $\begin{array}{l}\text { Normal } \\
\text { serum }\end{array}$ & Saline \\
\hline $\begin{array}{l}1 \mathrm{ml} . \\
1 \mathrm{ml} . \\
1 \mathrm{ml} . \\
1 \mathrm{ml} .\end{array}$ & $\begin{array}{l}0.4 \mathrm{ml} \text {. } \\
0.6 \mathrm{ml} . \\
0.8 \mathrm{ml} \text {. } \\
1.0 \mathrm{ml} .\end{array}$ & $\begin{array}{l}0.6 \mathrm{ml} \text {. } \\
0.6 \mathrm{ml} \text {. } \\
06 \mathrm{ml} \text {. } \\
0.6 \mathrm{ml} \text {. }\end{array}$ & $\begin{array}{l}+ \\
++ \\
++ \\
+ \pm\end{array}$ & $\begin{array}{l}+ \\
\text { Nil } \\
\text { Nil } \\
\text { Nil }\end{array}$ & $\begin{array}{l} \pm \stackrel{ \pm}{\text { Nil }} \\
\text { Nil } \\
\text { Nil }\end{array}$ \\
\hline
\end{tabular}


especially at the end-points of quantitative tests.) At the end of this time the precipitate which has formed is swung to the bottom of the tube by centrifugalization (2,000 r.p.m.) for 10 minutes. The supernatant fluid can then be poured off with safety and any remaining fluid allowed to drain out by placing the tube for five minutes on a filter paper in the inverted position. Any fluid still left on the sides of the tube can be wiped off with a towel and $12 \mathrm{ml}$. of normal saline added to the precipitate at the bottom of the tube. The mixing of the precipitate and the saline is accomplished by means of a Wright's capillary pipette, and the resulting suspension is transferred to a brown glass bottle either with a glass stopper or vulcanite screw cap. Tinfoil stoppers are to be avoided, since the antigen is acid enough to set up a reaction with the metal. In order to avoid infection of the made-up antigen, $0.022 \mathrm{ml}$. of sodium azide, 6.8 per cent, is added to each ml. of the suspension. When not in use the antigen should be kept in the ice chest at $4^{\circ} \mathrm{C}$. In addition the antigen pipette should have a cotton-wool plug at the teat end and should be rinsed out with acetone and dried before use. If kept thus, the antigen remains active for months.

Sera.-The sera to be tested are obtained in exactly the same manner as those subjected to a Wassermann reaction and are inactivated for thirty minutes at $56^{\circ} \mathrm{C}$.

\section{SCREEN TEST}

Each serum to be tested has two tubes allotted to it. Into one is put 5 volumes of neat serum and into the other 5 volumes of serum diluted 1 in 2 with saline. When testing large numbers of sera it is advisable to use the saline dropper in conjunction with Donald's dropping apparatus. This will deliver automatically five volumes of saline per drop, and this five volumes of saline can be rapidly delivered into each tube of the back row. Five volumes of the appropriate neat serum can then be added to each of the respective tubes of the front and back rows, five volumes from the latter being discarded after thorough mixing.* One volume of antigen is now added to all tubes necessary for the batch of sera under test.

\section{Screen Test \\ Tube 25 volumes of serum diluted 1 in 2 \\ 1 volume of antigen}

\footnotetext{
*It had been hoped to make the screen reaction a one-tube test using neat serum alone. With experience it was found that some strongly reacting sera contained too much reagin for the amount of antigen employed, thus suppressing the precipitation reaction. This zone phenomenon can be overcome successfully by using the two-tube technique.
}

\author{
Tube 15 volumes of neat \\ serum. \\ 1 volume of antigen.
}

The rack containing the tubes is placed for five minutes in a shaking apparatus (280 oscillations per minute). Subsequently $1 \mathrm{ml}$. of normal saline is added to each tube. The contents of the tubes are now well mixed by gentle agitation of the rack, and the results read by means of $\times 6$ lens and the slit lamp. When reading results the tube should be held on the slant and the particles, if any, looked for in the elliptical disc formed by the top of the fluid. The lowest positive reading is recorded if small discrete greyish particles of similar size are seen. Stronger reactions cause a greater number of particles which agglutinate and form a greyish-white precipitate, whilst the strongest reactions result in particles easily visible to the naked eye. These particles appear as large white flocculi. In tubes in which no reaction takes place the fluid contains no particles and is of a uniform clarity.

The sera giving negative results are recorded, and those giving positive results are dealt with by means of the quantitative test.

\section{Quantitative Test}

The quantitative test is set up on the principle of diluting the serum by a series of twofold dilutions.

Four tubes are allotted to sera giving weak reactions, and eight tubes to those giving strong reactions. All tubes except the first receive five volumes of saline, and if large numbers of positive sera are to be dealt with it is advisable to use the saline dropper in conjunction with Donald's dropping apparatus. The first and second tubes each receive five volumes of the serum to be tested. The contents of tube 2 are well mixed, and five volumes are carried over to tube 3 . The mixing and carrying is repeated from tube to tube in serial order until the last one is reached, when five volumes of the mixture are discarded leaving five volumes of this dilution in the tube. Thus the series of tubes allotted to each serum contains one of neat serum, and dilutions from 1 in 2 to 1 in 128 depending on the number of tubes used. All tubes now receive one volume of the antigen and are shaken for five minutes on the shaker.

\begin{tabular}{|c|c|c|c|}
\hline Strc & $\begin{array}{l}\text { gly Reacting } \\
\text { Serum } \\
5 \text { volumes o }\end{array}$ & $\mathrm{m}$ diluted & ative Test \\
\hline Tube 4 & $1-8$ & Tube 5 & $1-16$ \\
\hline Tube 3 & $1-4$ & Tube 6 & $1-32$ \\
\hline Tubs 2 & $1-2$ & Tube 7 & $1-64$ \\
\hline Tube 1 & Neat serum & Tube 8 & $1-128$ \\
\hline
\end{tabular}


With high titre serums the dilutions may have to be carried further.

One ml. of saline is then added to each tube by means of the simple apparatus shown in Fig. 2.

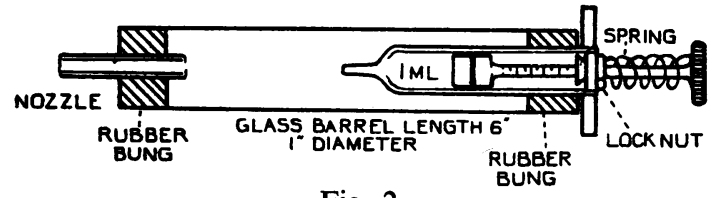

Fig. 2

The barrel of the apparatus holds approximately $30 \mathrm{ml}$. of saline, and each time the plunger is pushed home against the spring $1 \mathrm{ml}$. is delivered through the nozzle when once the locknut on the plunger inside the small syringe has been suitably adjusted. This simple apparatus saves much time and labour. Mixing of the contents is ensured by gentle agitation before reading with $\times 6$ lens and stit lamp. The tube containing the highest dilution of the serum which gives the lowest positive reading (that is, small discrete greyish particles of similar size seen in the elliptical disc at the top of the slanted tube) is noted. From this the number of units is calculated. For example, if the tube containing neat serum is the only one to show any particles (this is the lowest positive reading) the titration is recorded as 5 units on the grounds that no serum test is proven to be sensitive enough to demonstrate the extreme limits of the small amounts of reagin present in some syphilitic sera. If, on the other hand, the highest dilution of serum recording a positive reaction is 1 in 64 , then the titre of the serum is recorded as 320 units. Occasionally sera from patients suffering from florid secondary syphilis or multiple gummata record positive readings above the eight-tube dilution, the record so far being the tenth tube (2,560 units).

Thus the readings of the test are recorded in terms of units such as 0,5 , or multiples of five, and are designed to give a rough idea of the relative activity of the diseass.

\section{Cerebrospinal Fluid}

This test has been adapted to testing the cerebrospinal fluid, and, although the numbers tested as yet are relatively small, no fluid has been met which recorded any degree of positivity with the Wassermann reaction and failed to record a positive P.P.R. for syphilis.

The technique is similar to that used with the serum, and is as follows:

By the principle of optimum proportions it has been ascertained that the best results are obtained when 15 volumes of cerebrospinal fluid are used with 1 of antigen.
Screen test.-Each cerebrospinal fluid has one $\stackrel{\vec{\rho}}{\vec{\rho}}$ tube allotted to it, into which one volume of antigen $\bar{c}$ and 15 volumes of cerebrospinal fluid are placed $\frac{\bar{F}}{\bar{T}}$ and shaken for five minutes. At the end of this time $\frac{\bar{m}}{\frac{D}{2}}$ $0.5 \mathrm{ml}$. of saline is added to each tube, the contents $\stackrel{\mathbb{D}}{\square}$ of which are mixed by gentle agitation and the results read in the manner described for sera. All positively reacting fluids are put up for a quantitative test.

Quantitative test.-Each cerebrospinal fluid is $\frac{\Omega}{\circ}$ allotted eight tubes. All tubes excepting the first ? receive fifteen volumes of saline, and the first and $\vec{i}$ second tubes receive fifteen volumes of cerebro- 0 spinal fluid each. Serial dilutions of from 1-2 to 1-128 are made by mixing and carrying over fifteen volumes from tube to tube until the last is $\vec{T}$ reached, when, after mixing, fifteen volumes of the $\mathbb{D}$ mixture are discarded. Thus each positive cerebrospinal fluid has a series of tubes containing fifteen $\stackrel{\varrho}{\rightleftharpoons}$ volumes of the neat fluid and fifteen volumes of a series of dilutions from 1-2 to 1-128. Each tube now receives one volume of the antigen and is 90 shaken for five minutes, and subsequently $0.5 \mathrm{ml}$. 응 of saline is added. Mixing of the contents of the tube is secured by gentle agitation and results read and recorded in the same manner as for sera.

Cerebrospinal fluids require no treatment and are $\stackrel{\mathbb{D}}{\circ}$ suitable for test provided they are reasonably free $\overrightarrow{\vec{B}}$ from foreign matter. The highest recording from a cerebrospinal fluid to date is 160 units.

\section{Results}

Over 8,000 routine tests have been done in parallel with the Wassermann reaction and Kahn test, with extremely satisfactory results. In order to assess the value of this test as against the Wassermann and Kahn tests, the results of 2,936 routine parallel tests have been examined. These tests were the yield of three months' routine testing and are unselected. The results were as follows:

$$
\begin{aligned}
& \text { Agreements } \\
& \begin{array}{rrr}
\begin{array}{l}
\text { Negative reactions } \\
\text { Positive reactions }
\end{array} & \ldots & 2,459(83.7 \%) \\
\text { Total } & \ldots & 2,817(95.9 \%)
\end{array} \\
& \text { Disagreements } 119 \text { (4.1\%) }
\end{aligned}
$$




$\begin{array}{lll}\text { Group 2. } & \text { P.P.R. } & \text { positive } \\ \text { Wassermann reaction } & \text { negative } \\ & \text { Kahn reaction } & \text { positive } 50 \text { sera. } \\ \text { Group 3. P.P.R. } & \text { positive } & \\ \text { Wassermann reaction } & \text { negative } \\ & \text { Kahn reaction } & \text { negative } 1 \text { serum. } \\ \text { Group 4. } & \text { P.P.R. } & \text { negative } \\ & \text { Wassermann reaction } & \text { positive } \\ & \text { Kahn reaction } & \text { negative } 1 \text { serum. } \\ \text { Group 5. P.P.R. } & \text { positive } \\ & \text { Wassermann reaction } & \text { positive } \\ & \text { Kahn reaction } & \text { negative } 1 \text { serum. } \\ & \end{array}$

Examination of the case cards of those patients whose sera gave conflicting results reveals that they were grouped into the following six types of case:

1. Primary syphilis untreated.-In this group there were 3 sera, all of which recorded positive Kahn tests. One serum reacted positively with the P.P.R. and negatively with the Wassermann reaction, whilst two sera gave negative results with these two tests.

2. Latent syphilis treated.-This was the largest class, consisting of 95 sera. All the patients had been treated with penicillin followed by arsenic and bismuth. All the sera recorded negative Wassermann reactions. There were 3 results which were possible false positive Kahn reactions. For the rest, the noticeable feature was that usually the Wassermann became negative first, then the P.P.R., which was followed a month or two later by the Kahn test. A reversal of a negative P.P.R. to positive occurred on only two occasions.

3. Latent syphilis untreated.-In this group there were only two sera, both of which recorded negative Wassermann reactions, but positive P.P.R.s and Kahn tests.

4. Old cured syphilis.-One serum was tested from a patient who had had syphilis in 1924. He came up for a check blood test, but showed no signs or symptoms. In a series of three tests done within a month the Kahn was positive on one occasion, whilst the Wassermann and P.P.R. were negative at each testing.

5. Patients attending for treatment for gonorrhoea.-There were 12 of these sera, 9 of which recorded negative Wassermann and P.P.R. reactions, but positive Kahns. Of these 9 patients, who were under observation for months, none revealed any clinical or serological evidence of syphilis, apart from the Kahn test. The remaining 3 were problem sera. One gave persistently positive Kahn and P.P.R. results with negative Wassermann reactions over a period of three months. He was given 150,000 units of penicillin at the outset of his gonorrhoeal infection, but after two months there was no evidence of syphilis. He remains under observation. Patient 2 was a coloured patient who reported that he had had yaws as a youth. He attended with gonorrhoea and received 150,000 units of penicillin, followed by a further 200,000 units. Over a period of three months he persistently recorded negative Wassermann and positive Kahn and P.P.R. reactions. There was no clinical evidence of syphilis, and he remains under observation. Patient 3 attended with gonorrhoea, recording a negative Wassermann but a positive Kahn and P.P.R. There was no evidence of syphilis and he was given 150,000 units of penicillin. Six days later his blood recorded all three tests as positive. Unfortunately the patient defaulted so no opinion could be given, but possibly he had a double infection of gonorrhoea and syphilis, the latter being first detected by the P.P.R. and Kahn tests.

6. Sera from patients in whom no evidence of venereal disease was found.-There were six of these sera, all of which recorded negative P.P.R. and Wassermann reactions but positive Kahn tests. None of these patients whilst under observation revealed any evidence of syphilis in spite of repeated clinical examination and blood tests.

\section{Primary SyphiLIs}

In order to ascertain how soon after infection the P.P.R. becomes positive, the case records of all patients attending the Whitechapel Clinic and suffering from untreated primary syphilis during a period of six months were examined. The number totalled 80. Spirochaeta pallida had been demonstrated in the primary lesions in all cases.

Although it is difficult to be certain of the exact date of the infecting exposure, it was thought to be of sufficient interest to attempt to ascertain how soon after an exposure a positive P.P.R. would be recorded. Of 38 patients in the first four weeks after exposure, the serum of 19 (50 per cent) recorded a positive P.P.R. Of 29 patients in the fifth to eighth week after exposure the sera of 16 (55 per cent) recorded positive P.P.R. reactions. Finally, of 13 patients in the ninth to twelfth weeks after exposure the sera of 7 (53 per cent) recorded positive P.P.R. reactions. It should be noted that the parallel Wassermann reactions and Kahn tests were identical.

\section{Cerebrospinal Fluid}

During this investigation a total of 284 cerebrcspinal fluids were tested in parallel with the Wassermann reaction. Of these, both tests recorded 13 
positive and 271 negative reactions. The highest unit value yet recorded by the test with cerebrospinal fluid was 160 , and it appears that values of 5 to 10 units suggest a condition of tabes dorsalis, whilst higher values are more typical of fluids obtained from patients suffering from general paralysis of the insane.

\section{Comment}

Whilst this examination of results is not regarded as exhaustive, it does seem to show that the P.P.R. is at least as sensitive as the Wassermann reaction and somewhat more specific than the Kahn test. Thus, of 9 patients suffering from gonorrhoea and 6 in whom no signs of venereal disease were discovered, all recorded negative P.P.R. but positive Kahn tests. These latter seem to be false positives, particularly as the Wassermann as well as the P.P.R. reactions were negative. They represent 15 (12 per cent) out of the total of 119 conflicting results recorded by parallel Wassermann, Kahn, and P.P.R. reactions respectively, or 0.5 per cent of the total number of sera $(2,936)$ examined. Of these same sera only 2 appeared to give false positive P.P.R. reactions.

Consideration of the results obtained by this test suggests that the quantitative test gives some indication of the activity of the disease. In general terms it may be said that the greater the number. of units recorded by a serum, the more active is the spirochaetal infection. Sera from patients suffering from florid secondary syphilis or multiple gummata always record a high unit value, and the cerebrospínal fluids from patients suffering from general paralysis of the insane record higher readings than the cerebrospinal fluids of tabetics.

\section{Summary}

1. The experimental work underlying a serum precipitation test for syphilis is given.

2. The preparation of the alcoholic extract from the raw ox heart is described. This operation is well within the capacity of any moderately wellequipped laboratory.

3. The preparation of the antigen from the alcoholic extract of ox heart and its'standardization for use in the test is given in detail.

4. The screen test as described is simple, speedy, reliable, and easily read.

5. The method for the quantitative test is given; the test gives some idea of the activity of the disease.

6. The testing of cerebrospinal fluids (which require no prior preparation) is shown to give results equal to those of the Wassermann reaction.

7. The results of 2,936 routine parallel tests with the Wassermann and Kahn tests are examined.

I would like to express my indebtedness to Mr. Tweed, senior technician to the V.D. Reference Laboratory, and to Dr. Wilkinson, assistant pathologist to the Whitechapel Clinic, for much help in the routine work of this investigation.

\section{REFERENCES}

Price, I. N. Orpwood (1946a). Mon. Bull. Min. Hlth. Emerg. publ. Hlth. Lab. Serv., $5,43$.

Price, I. N. Orpwood (1946b). Mon. Bull. Min. Hlth. Emerg. publ. Hlth. Lab. Serv., 5, 44.

Price, I. N. Orpwood (1946c). Mon. Bull. Min. Hlth. Emerg. publ. Hith. Lab. Serv., $5,45$.

W.yler, E. J. (1929). Med. Res. Cncl. Spec. Rep. Ser., No. 129. London. 